\title{
DEGRADATION EVALUATION USING MINIATURIZED TENSILE SAMPLES
}

\author{
${ }^{1}$ Martin RUND, ${ }^{1}$ Pavel KONOPÍK, ${ }^{2} J a k u b$ HORVÁTH, 'Eva CHVOSTOVÁ, ${ }^{1}$ Sylwia RZEPA, \\ ${ }^{2}$ Ladislav HORVÁTH
}

${ }^{1}$ COMTES FHT a.s., Dobřany, Czech Republic, EU, martin.rund@comtesfht.cz

${ }^{2}$ UJP PRAHA a.s., Praha, Czech Republic, EU, horvathj@ujp.cz

https://doi.org/10.37904/metal.2021.4154

\begin{abstract}
Many power plant operators are currently struggling with the problem of expiring the design life of components. The question often arises whether to continue the operation of the equipment or if it is already necessary to shut down/overhaul it. The knowledge of mechanical properties is therefore crucial. Semi-destructive sampling, subsequent production of mini tensile test specimens (M-TT) followed by mechanical testing can then provide the necessary information. The agreement between the results obtained using miniaturized and standard bodies has already been proven by many authors. The aim of this paper is to demonstrate that the use of MTT is possible even in the case of severely degraded materials. The experiment was performed on SUPER $304 \mathrm{H}$ austenitic steel in the ground state and in the degraded state
\end{abstract}

Keywords: Miniaturization, tensile test, degradation, SUPER $304 \mathrm{H}$, elevated temperature

\section{INTRODUCTION}

Nowadays, energy industry tends to increase productivity, flexibility, and thus, complexity of power plants. In addition, the operating equipment have to meet the safety requirements. The power plant operators need to be aware of the current plant condition. Therefore, a regular monitoring of the state of equipment utilized in terms of mechanical properties is crucial. However, the problem is often the need to shut down the component for sample extraction for experiments. Therefore, semi-destructive sampling of a small amount of material is usually successfully used to evaluate the current condition of a component. This amount of material can be then used for miniaturized mechanical tests to assess the degree of degradation. However, the transferability of the obtained results to standard bodies is not always unambiguous.

To comprehend the knowledge about this phenomena, our institute is involved in a project (FW01010368), in which individual types of miniaturized specimens such as tensile tests specimen (M-TT), Charpy test specimen (KLST), Compact tension specimen for fracture toughness tests (MCT), and the specimen for measurement of the dynamic modulus are applied. All the results obtained using above mentioned miniaturized specimens are compared to standard-sized samples and evaluated in terms of their ability to detect material degradation. The agreement between M-TT and standard specimens has already been proven by many authors [1-4].

The aim of this paper is to show that the application of M-TT is possible even in the case of severely degraded materials. The experiment was performed on SUPER $304 \mathrm{H}$ austenitic steel in the ground and degraded state. This material it is a typical representative of materials used in the energy industry.

\section{MATERIAL SPECIFICATION}

Most of the performed experiments were done at the material SUPER $304 \mathrm{H}$ because of its great availability. The specification of steel is listed in [5]. The material was supplied by Sumitomo Metals. Steel SUPER $304 \mathrm{H}$ was delivered in the form of the seamless tubes with outer diameter $38 \mathrm{~mm}$, wall thickness $6.3 \mathrm{~mm}$ and a tube 
length of $5700 \mathrm{~mm}$ [5]. The heat treatment performed by producer (Sumitomo) was solution annealing under the following conditions: $1150{ }^{\circ} \mathrm{C} / 2 \mathrm{~min}$ holding/cold water quenching [5].

The heat number of supplied steel is F124139. Its chemical composition is summarized in Table 1. The supplied steel is designed in accordance with prescribed values by the standard ASME Case 2328-1. The mechanical properties of the material in delivered condition are listed in [5].

Table 1 Chemical composition of supplied steel SUPER 304H (in wt\%) [5]

\begin{tabular}{|l|c|c|c|c|c|c|c|c|c|c|c|c|}
\hline & $\mathrm{C}$ & $\mathrm{Si}$ & $\mathrm{Mn}$ & $\mathrm{P}$ & $\mathrm{S}$ & $\mathrm{Cu}$ & $\mathrm{Cr}$ & $\mathrm{Ni}$ & $\mathrm{Nb}$ & $\mathrm{B}$ & $\mathrm{N}$ & $\mathrm{Al}$ \\
\hline Min. (ASME Case 2328-1) & 0.07 & - & - & - & - & 2.50 & 17.0 & 7.5 & 0.30 & 0.001 & 0.05 & 0.003 \\
\hline Max. (ASME Case 2328-1) & 0.13 & 0.30 & 1.00 & 0.04 & 0.01 & 3.50 & 19.0 & 10.5 & 0.60 & 0.010 & 0.12 & 0.030 \\
\hline Heat No. F124139 & 0.08 & 0.25 & 0.81 & 0.003 & - & 3.07 & 18.3 & 9.0 & 0.49 & 0.004 & 0.11 & 0.005 \\
\hline
\end{tabular}

\section{AGEING}

A laboratory isothermal aging on air was used to reach the degraded state of the austenitic steel SUPER 304H. The processing temperature was selected as $675{ }^{\circ} \mathrm{C}$, which is slightly higher in comparison with operation parameters of USC power plant. The increase of temperature is motivated by the degradation processes acceleration. The time of isothermal ageing was up to 27000 hours.

The experimental material in three various states was used for testing, i.e. the base material without any thermal exposition (degradation state 0 ) and two exposed states: after 12000 (degradation state 1 .) and 27 000 hours (degradation state II.). Those exposition states may simulate the operation degradation with related precipitation processes. In fact, the second exposition time (degradation state II.) correspond with nearly end of power plant lifetime according Larson-Miller parameter (LMP) construction.

\section{METALLOGRAPHY}

The base material (Figure 1) can be described as fully austenitic with twins and a presence of niobium carbonitrides. After thermal exposition, sigma phase precipitated at triple grain boundaries points and at the grain boundaries (Figure 2). Sigma phase is composed of brittle intermetallic particles which affect the mechanical properties.

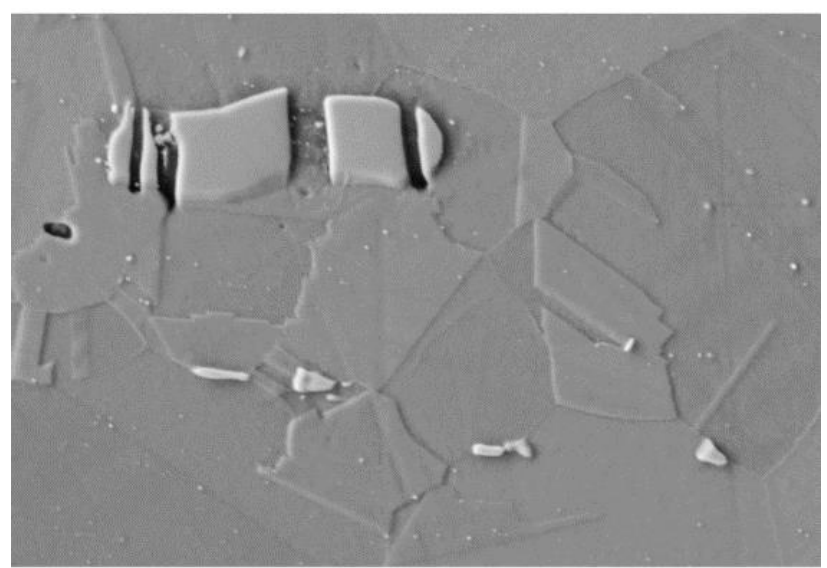

Electron Image 1

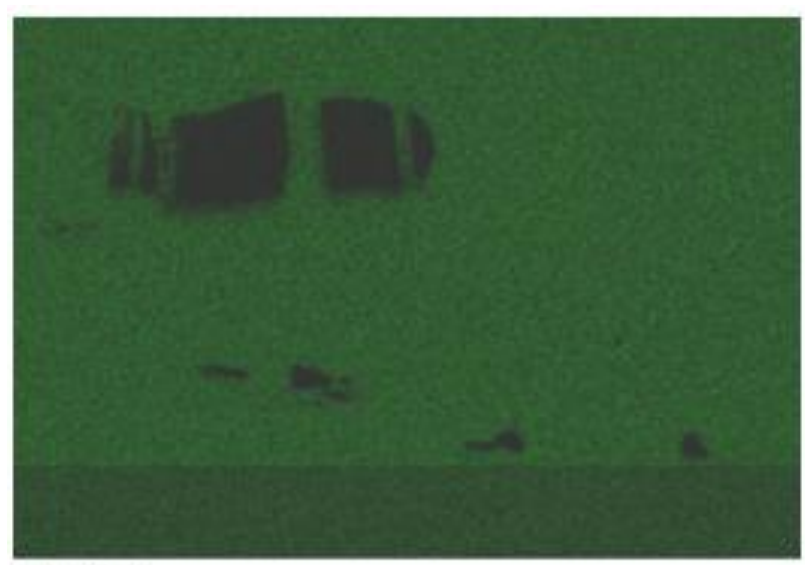

$\mathrm{Cr} \mathrm{Ka} 1$

Figure 1 Microstructure of base material [6] 

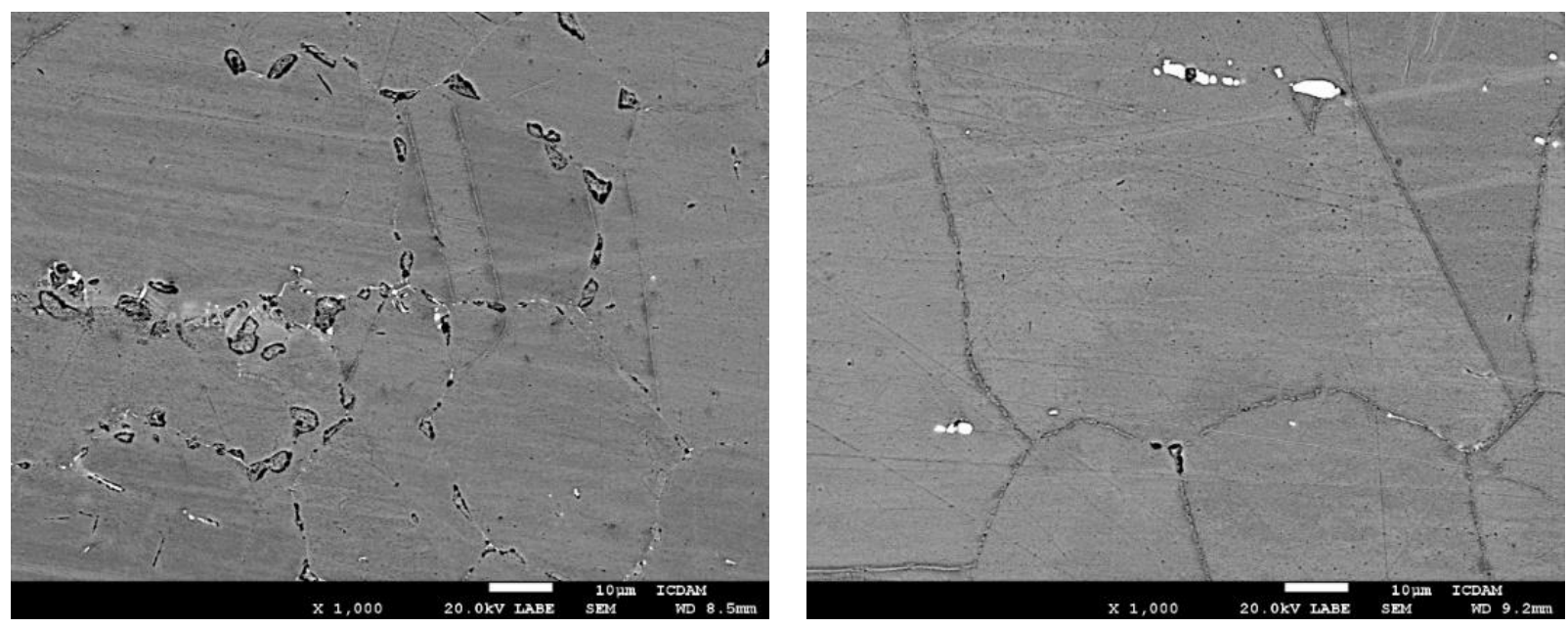

Figure 2 Microstructure of aged material [6]

\section{EXPERIMENT - TENSILE TEST}

The geometries of the standard (St) and miniaturized (M-TT) specimens are presented in Figure 3. The M-TT specimens were extracted using an electrical discharge machining (EDM) by several-passes of the wire to get the high-quality surface. The standard specimens were produced by CNC machines and tested according to the standard CSN EN ISO 6892-1 [7] on an electro-mechanic testing machine. The strain was monitored by means of contact extensometer Epsilon with $\mathrm{L}_{0}=25 \mathrm{~mm}$. The M-TT specimens were tested according to the internal methodology RD 2/30, which is accredited and follows the standard CSN EN ISO 6892-1/ASTM E8 [8]. The M-TT tests were carried out on a universal testing machine TiraTest with a linear drive and the load capacity of $10 \mathrm{kN}$. The testing machine was equipped with the mechanical grips suitable for testing miniaturized specimens. The testing setup can be seen in Figure 4. Due to small specimen size, a single camera with the MERCURY RT (real-time tracking) system were set up. The deformation was tracked by means of optical extensometer based on Digital Image Correlation technique (DIC)[9]. Prior to testing, a stochastic pattern was applied on the specimens' surface with ratio of $50 \%$ white and $50 \%$ black colour to allow the deformation tracking by the optical system. All tests were performed under quasi-static conditions (strain rate $-0.00025 \mathrm{~s}-1)$.

The hardening coefficients were evaluated according to the standard ČSN EN ISO 10275 [10] in a deformation range $2 \%$-Ag. All test results are summarized in Table 2. A comparison of the resulting flow plastic curves is shown in Figure 5. The resulted hardening coefficients are presented in Figure 6 and Figure 7.
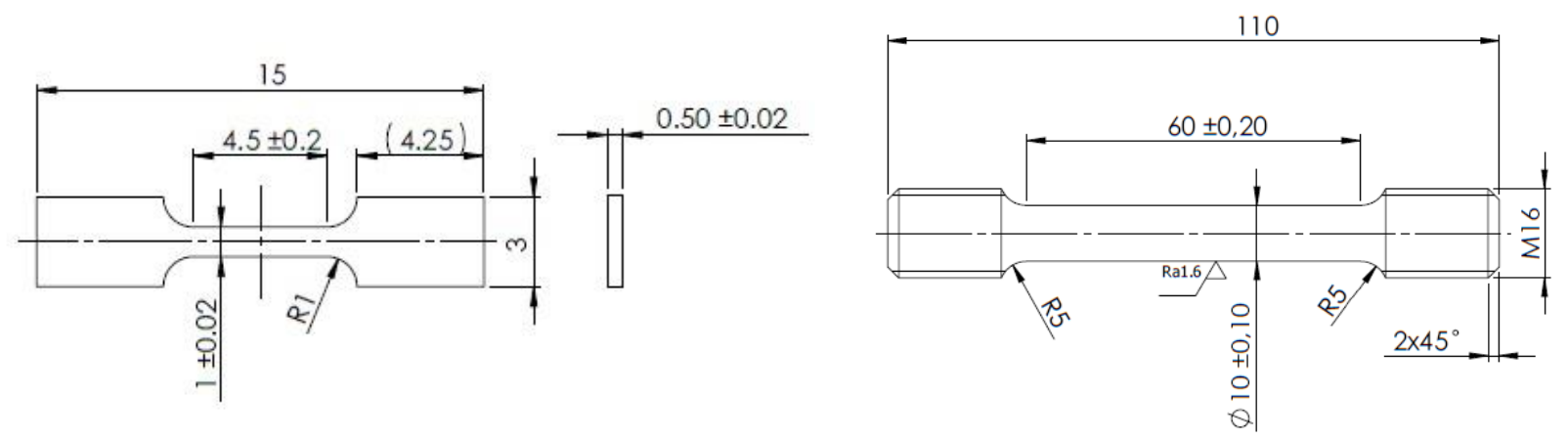

Figure 3 Geometry of the specimens, LEFT - M-TT; RIGHT - Standard 

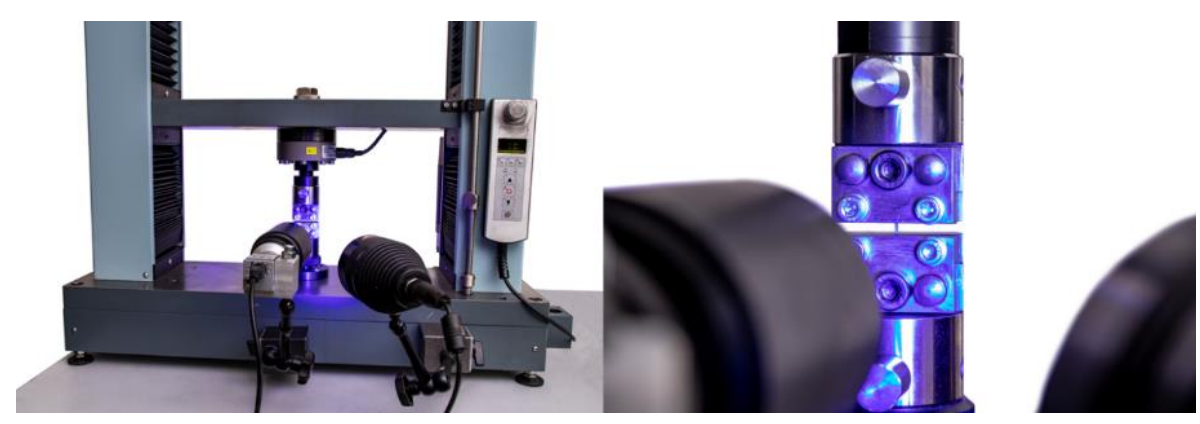

Figure 4 Quasi-static mini-tensile test setup

Table 2 Resulting hardening coefficients for individual geometries and degradation states

\begin{tabular}{|c|c|c|c|c|c|c|}
\hline Geometry & $\begin{array}{c}\text { Temperature } \\
{ }^{\circ} \mathrm{C}\end{array}$ & $\begin{array}{c}\mathbf{n}_{2-\mathrm{Ag}} \\
-\end{array}$ & $\begin{array}{c}\text { n_St.dev } \\
-\end{array}$ & $\begin{array}{l}\mathrm{C}_{2-\mathrm{Ag}} \\
\mathrm{MPa}\end{array}$ & $\begin{array}{c}\text { C_St.dev } \\
\mathrm{MPa}\end{array}$ & $\begin{array}{l}\text { Degradation } \\
\text { state }\end{array}$ \\
\hline \multirow{6}{*}{ M-TT } & 20 & 0.30 & 0.002 & 1182.4 & 11.2 & 0 \\
\hline & 20 & 0.29 & 0.005 & 1390.9 & 3.7 & I. \\
\hline & 20 & 0.28 & 0.003 & 1412.7 & 25.9 & II. \\
\hline & 600 & 0.34 & 0.007 & 955.5 & 9.1 & 0 \\
\hline & 600 & 0.20 & 0.007 & 689.7 & 4.1 & II. \\
\hline & 600 & 0.21 & 0.006 & 674.2 & 4.9 & I. \\
\hline \multirow{6}{*}{ Standard } & 20 & 0.31 & 0.004 & 1242.1 & 4.8 & 0 \\
\hline & 20 & 0.29 & 0.001 & 1374.6 & 9.3 & I. \\
\hline & 20 & 0.27 & 0.005 & 1353.9 & 17.9 & II. \\
\hline & 600 & 0.32 & 0.004 & 968.0 & 13.5 & 0 \\
\hline & 600 & 0,19 & 0,003 & 669,0 & 5,6 & I. \\
\hline & 600 & 0,17 & 0,005 & 658,9 & 9,7 & II. \\
\hline
\end{tabular}
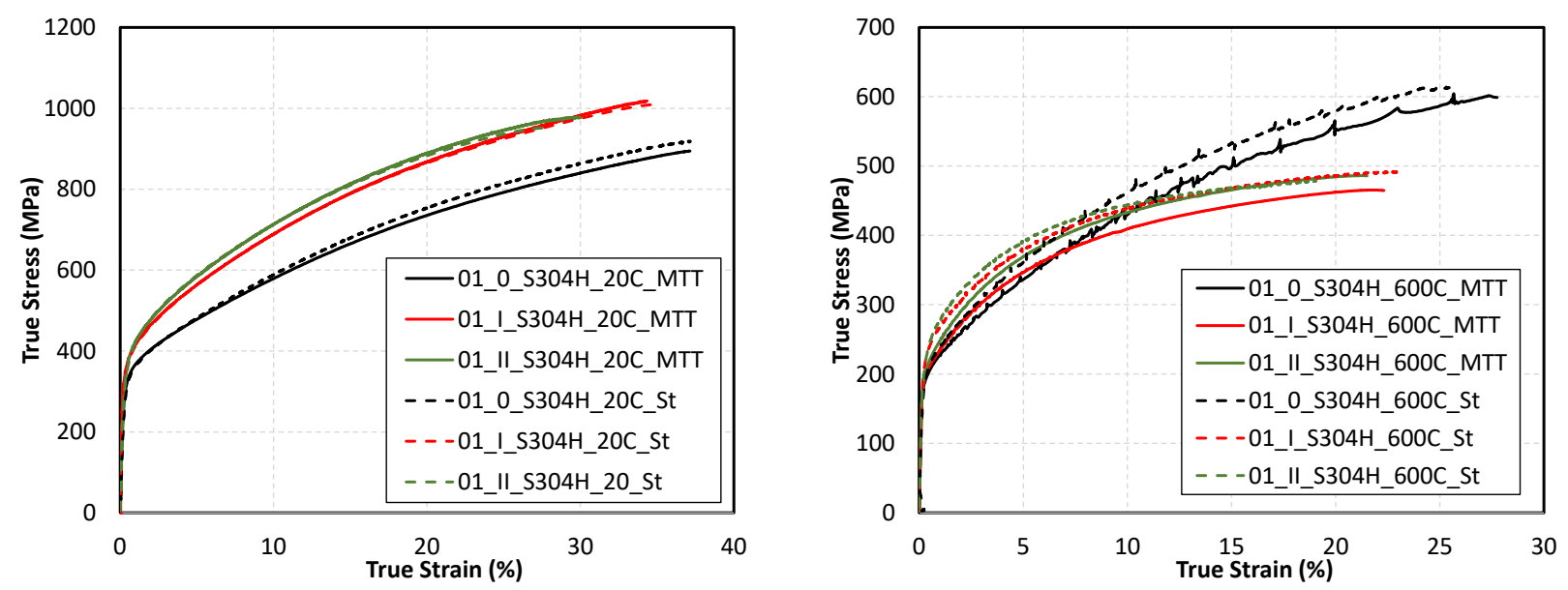

Figure 5 Comparison of the results obtained using miniaturized and standard tensile test specimens.

Degradation state 0, I and II. Temperature LEFT $-20^{\circ} \mathrm{C}$; RIGHT $-600^{\circ} \mathrm{C}$ 

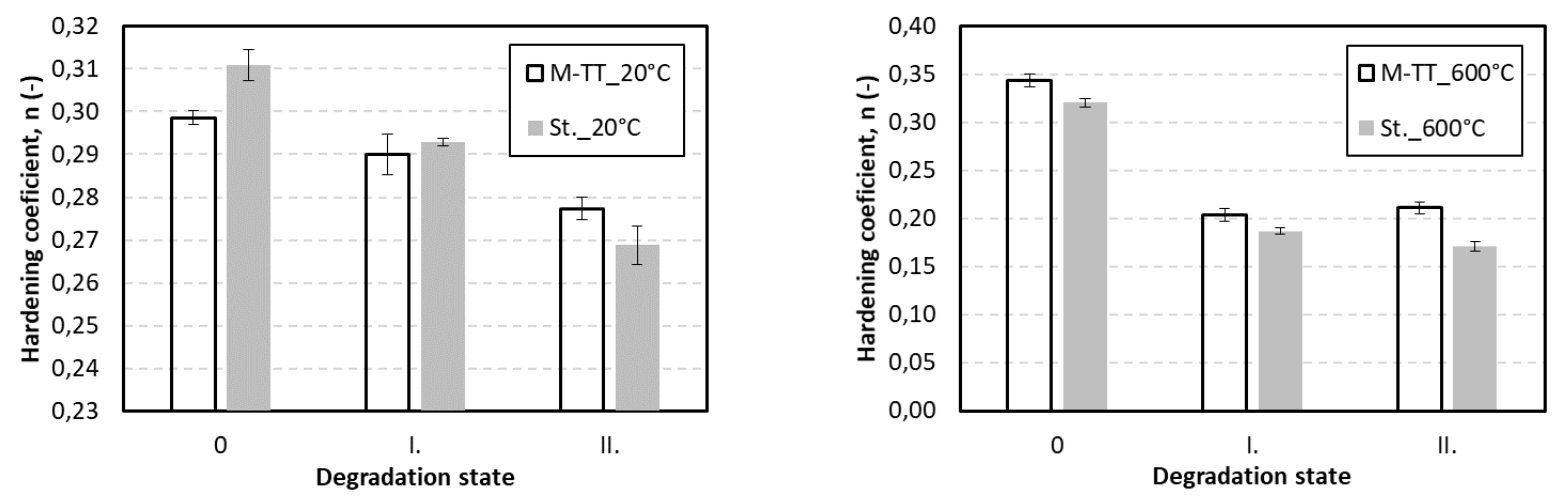

Figure 6 Comparison of the hardening exponent " $\mathrm{n}$ " for miniaturized and standard specimens, LEFT - at $20^{\circ} \mathrm{C}$; RIGHT - at $600{ }^{\circ} \mathrm{C}$
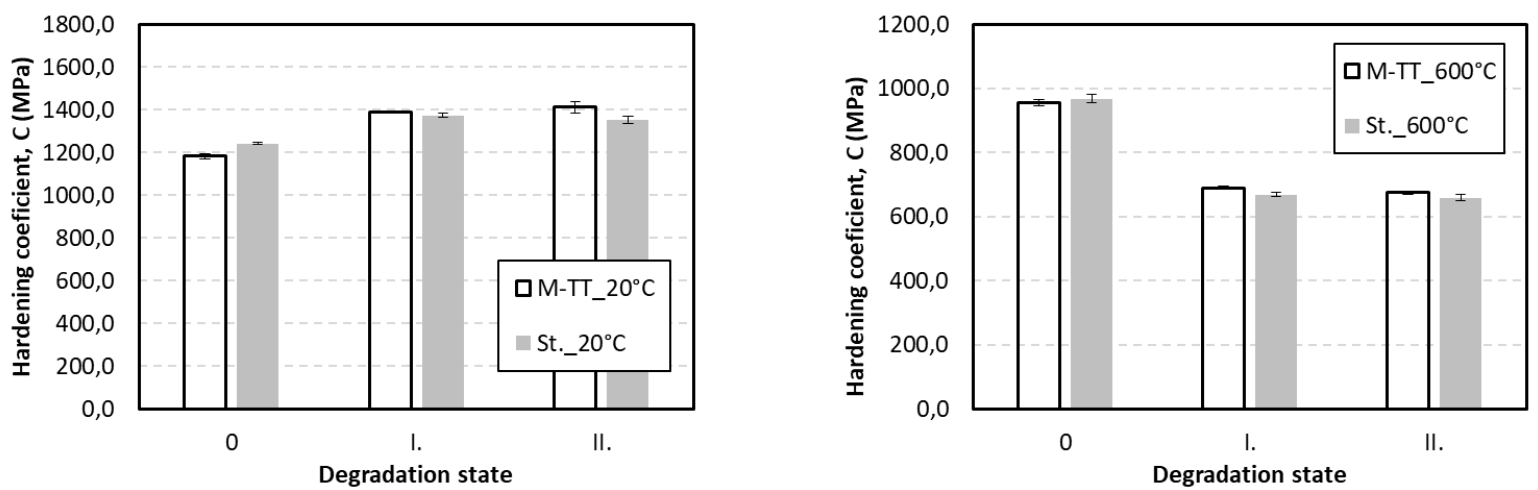

Figure 7 Comparison of the hardening coefficient "C" for miniaturized and standard specimens,

LEFT - at $20^{\circ} \mathrm{C}$; RIGHT - at $600^{\circ} \mathrm{C}$

\section{CONCLUSIONS}

The results show good agreement of the values obtained using miniaturized and standard specimens. Furthermore, the MTT specimens are characterized by sensitivity to the material degradation. This is also shown by the fact that the Portevin-Le Chatelier effect (PLC) was visible on M-TT at the temperature of 600 ${ }^{\circ} \mathrm{C}$ on non-degraded material. In the case of degradation at stage I. and II., the PLC was not observed. The variance of the results was also approximately the same. Future tests will focus on performing of the same assessment on another ferritic-pearlitic material used in the energy industry.

\section{ACKNOWLEDGEMENTS}

This article was created within the project "Evaluation of degraded steels for the construction of turbines and superheaters of power plant boilers" No. FV40166, which is implemented with financial support from the state budget through the Ministry of Industry and Trade in the TRIO program.

\section{REFERENCES}

[1] SOKOLOV, M. A., LUCON, E. Small specimen test techniques: 6th Volume. West Conshohocken: ASTM INTERNACIONAL, 2015. ISBN 978-0-8031-7597-6. 
[2] KONOPÍK, P., DŽUGAN, J., RUND, M. Determination of fracture toughness in the upper shelf region using small sample test techniques, In: METAL 2015: 24th International Conference on Metallurgy and Materials. Brno: Tanger, 2015, pp. 710-715.

[3] LUCAS, G.E., ODETTE, G.R., MATSUI, H. et all. The role of small specimen test technology in fusion materials development. Journal of Nuclear Materials. [online]. 2007, Vol. 367-370, part B, pp 1549-1556. ISSN 0022-3115. Available from: https://doi.org/10.1016/j.jnucmat.2007.04.034.

[4] YUAN, W.J., ZHANG, Z.L., SU, Y.J. influence of specimen thickness with rectangular cross-section on the tensile properties of structural steels. Materials Science and Engineering: A. [online]. 2012, vol. 532, pp. 601-605. ISSN 0921-5093.Available from: https://doi.org/10.1016/j.msea.2011.11.021.

[5] Inspection certificate: Super 304H - heat F124139. 1. Japan: Sumitomo metals, 2011.

[6] HORVÁTH, J., KRÁL, P., JANOVEC, J., SKLENIČKA, V. The effect of sigma-phase formation on long-term durability of super 304h steel. In: Metal 2015: 24th international conference on metallurgy and materials. Brno, Czech Republic: Tanger. 2015, pp. 505-510. ISBN 978-80-87294-62-8.

[7] ČSN EN ISO 6892-1. Kovové materiály - zkoušení tahem - část 1: zkušební metoda za pokojové teploty. Česká agentura pro standardizaci. Leden 2021.

[8] E8/E8M. Standard test methods for tension testing of metallic materials. ASTM international, 2016

[9] SUTTON, M. Digital image correlation: principles develpments and applications for paramter estimation, University of South Carolina. Available from: http://www.gdr2519.cnrs.fr /ecole2011/ET 2011/M Sutton.pdf.

[10] ČSN EN ISO 10275. Kovové materiály - plechy a pásy - stanovení exponentu deformačního zpevnění tahem. Česká agentura pro standardizaci, 2018. 